\title{
PENERAPAN MODEL PEMBELAJARAN TWO STAY TWO STRAY UNTUK PENINGKATAN HASIL BELAJAR KETERAMPILAN DISKUSI SISWA KELAS X IPA3 SMA NEGERI 3 SINGKAWANG
}

\author{
SRI WAHYUNI \\ SMA Negeri 3 Singkawang \\ e-mail. sriwahyuniaasri@gmail.com
}

\begin{abstract}
ABSTRAK
Penelitian ini bertujuan untuk meningkatkan proses pembelajaran diskusi dan meningkatkan keterampilan diskusi siswa kelas X IPA2 melalui model pembelajaran Two Stay Two Stray. Model pembelajaran Two Stay Two Stray dipilih karena dapat memacu dan mendorong siswa untuk aktif berbicara menyampaikan ide/gagasan dalam kegiatan berdiskusi dengan menggunakan Penelitian Tindakan Kelas (PTK). Data diperoleh melalui observasi, dokumentasi yang berupa tugas-tugas siswa. Teknik analisis data dilakukan dengan teknik deskripsi kualitatif. Hasil penelitian: Hasil penelitian yang diperoleh yaitu persentase ketercapaian indikator keterampilan diskusi mengalami peningkatan pada setiap siklus. Kemampuan rata-rata siswa dalam berdiskusi sebelum adanya tindakan berkategori kurang. Namun, setelah tindakan selama dua siklus, kemampuan rata-rata siswa dalam berdiskusi menjadi berkategori baik. Hasil penelitian menunjukkan siswa dalam berdiskusi pada saat pratindakan dengan skor rata-rata 7,31 dan pada akhir pelaksanaan tindakan yakni siklus II menjadi 20,90. Kemampuan siswa dalam berdiskusi mengalami peningkatan sebesar 13,59.
\end{abstract}

Kata Kunci: Model Two Stay Two Stray, Keterampilan Diskusi

\section{PENDAHULUAN}

Diskusi merupakan kegiatan memecahkan sebuah permasalahan secara bersama-sama untuk mengambil kesimpulan dari permasalahan tersebut. Melalui diskusi, siswa berlatih untuk berkomunikasi dengan orang lain secara berkelompok. Siswa juga dituntut untuk aktif mengeluarkan ide/gagasan untuk memberikan pendapat tentang suatu permasalahan melalui kegiatan berdiskusi. Hal ini mampu merangsang kreativitas, motivasi, keberanian, membangun kerjasama kelompok, dan melatih sikap saat berkomunikasi dengan orang lain (Arsjad, dkk. 2010: 71). Pada pelaksanaan pembelajaran diskusi, seringkali siswa kurang mampu melakukan diskusi dengan tepat. Siswa hanya sekedar berdiskusi untuk melaksanakan tugas dalam mata pelajaran bahasa Indonesia tanpa memperhatikan tujuan dan manfaat dari pembelajaran tersebut. Banyak siswa mengalami kesulitan ketika harus mengungkapkan pikiran atau pendapatnya di hadapan teman sekelasnya. Siswa lebih banyak diam dan cenderung tidak aktif. Terlebih pada praktiknya, siswa sulit dalam menyampaikan gagasannya tentang sebuah permasalahan dalam sebuah forum. Oleh karena itu, siswa membutuhkan pemahaman mengenai apa itu diskusi dan bagaimana cara melakukan diskusi yang baik, khususnya berdiskusi dalam sebuah kelompok. Dari permasalahan di atas, diperlukan model pembelajaran yang tepat untuk meningkatkan keterampilan diskusi siswa.

Dari pengamatan yang peneliti lakukan bahwa pelaksanaan pembelajaran diskusi di kelas, seperti: siswa kurang mengetahui tentang diskusi yang baik, siswa cenderung pasif dan sulit untuk berbicara, siswa kurang berani dan kurang aktif dalam mengutarakan gagasan atau pikirannya pada saat kegiatan berdiskusi. Pembelajaran diskusi di kelas XI IPS1 SMA Negeri 3 Singkawang belum menggunakan model pembelajaran yang sesuai, sehingga pada pelaksanaannya belum berhasil secara optimal. Hal inilah yang menjadi permasalahan dalam pembelajaran diskusi. Oleh karena itu, peneliti mencoba menerapkan model pembelajaran Two Stay Two Stray dalam pembelajaran diskusi. 
Metode Two Stay Two Stray merupakan model pembelajaran kooperatif yang memberi kesempatan kepada kelompok untuk membagikan hasil dan informasi dengan kelompok lain. Banyak kegiatan belajar mengajar yang diwarnai dengan kegiatan-kegiatan individu, padahal pada kenyataan hidup di luar sekolah, manusia itu saling membutuhkan satu dengan yang lainnya (Lie, 2010: 62). Pada pembelajaran dengan metode ini siswa diajarkan untuk secara aktif melakukan diskusi secara berkelompok dan bekerjasama membahas sebuah permasalahan.

Kelebihan model pembelajaran Two Stay Two Stray ini dalam diskusi yakni siswa dapat aktif selama pembelajaran dan lebih menguasai permasalahan yang didiskusikan. Pelaksanaannya dilakukan dengan membentuk kelompok yang masing-masing anggota terdiri dari empat siswa dengan kemampuan yang heterogen. Siswa akan merasa memiliki tanggung jawab dan ketertarikan untuk melaksanakan kegiatan ini. Siswa juga lebih berwawasan luas, mempunyai ide, dan aktif mengungkapkan pikiran dan gagasan mereka (Alvin., A \& Carl., E.,Larson, 2010).

Dengan metode pembelajaran ini, siswa akan mampu berbicara karena langkah dalam metode Two Stay Two Stray mengharuskan siswa untuk berbicara dalam sebuah diskusi. Pembelajaran diskusi menggunakan metode Two Stay Two Stray diharapkan mampu menciptakan suasana pembelajaran yang aktif dan menarik serta menyenangkan bagi siswa. Selain itu, guru juga dapat lebih mudah dalam membimbing siswa. Penerapan metodeini diharapkan dapat menjadi alternatif bagi guru dalam pembelajaran diskusi agar semakin meningkat. Oleh karena itu, perlu dilakukan penelitian mengenai penerapan metode pembelajaran Two Stay Two Stray pada mata pelajaran Bahasa Indonesia dalam rangka membantu meningkatkan kemampuan diskusi siswa.

\section{METODE PENELITIAN}

Prosedur Penelitian Tindakan Kelas (PTK) dapat dilaksanakan melalui empat langkah utama yaitu: perencanaan (planning), pelaksanaan (acting), pengamatan (observing) dan refleksi (reflecting). Empat langkah utama dalam pelaksanaan Penelitan Tindakan Kelas (PTK) sering disebut dengan istilah satu siklus (Susilo, Herawati.dkk, 2009:19). Untuk lebih jelas berikut ini dikemukakan model siklus Penelitian Tindakan Kelas (PTK):

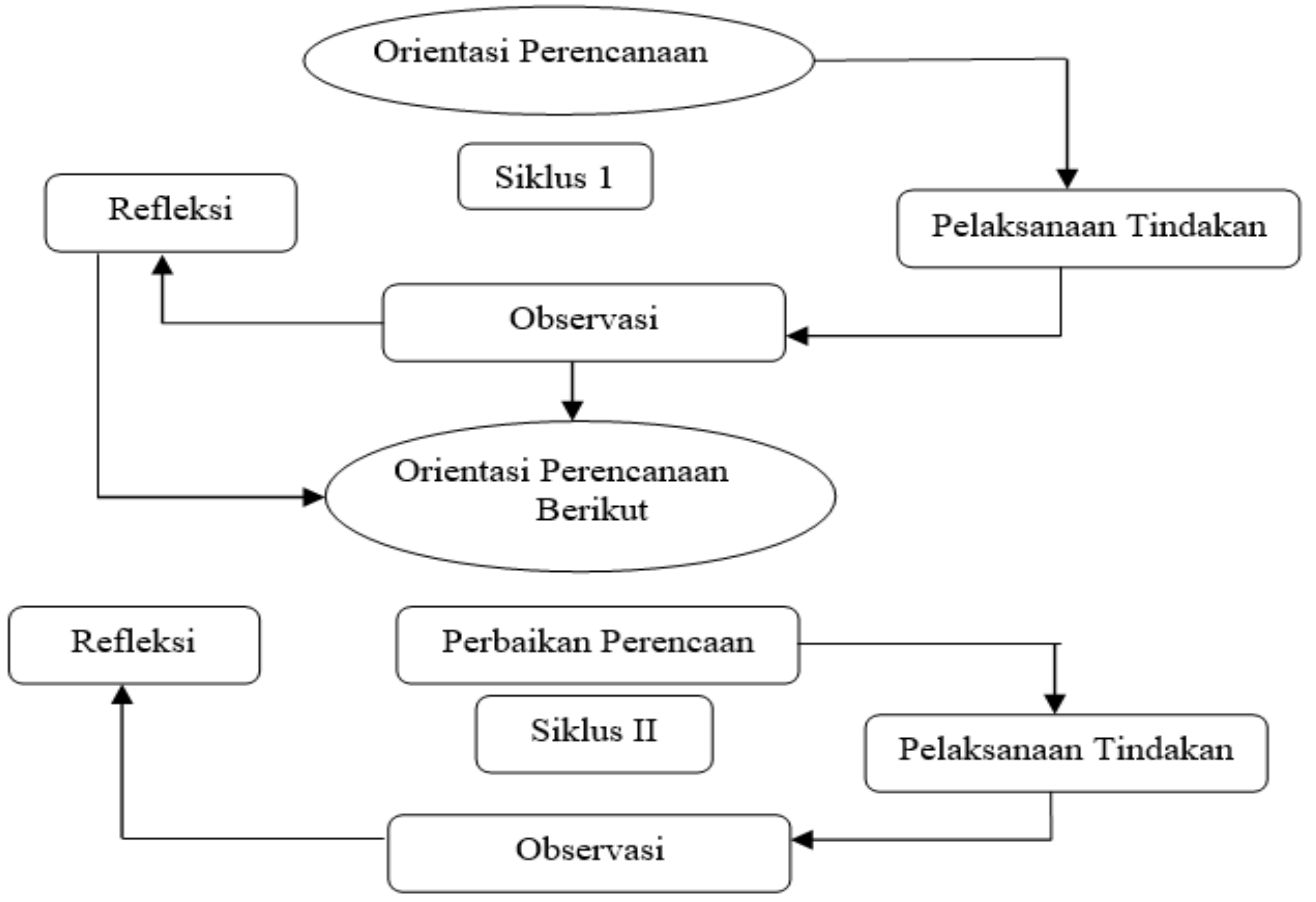

Gambar 1. Model siklus Penelitian Tindakan Kelas (PTK) 
Instrumen yang digunakan dalam penelitian ini yakni: pedoman pengamatan, lembar penilaian wawancara, catatan lapangan, dan dokumentasi kegiatan yaitu (1) Pedoman Pengamatan Pedoman pengamatan atau lembar observasi digunakan untuk mencatat data tentang proses kegiatan pembelajaran seperti sikap siswa, tingkah laku siswa, minat siswa, dan sebagainya (2) Pedoman Wawancara Pedoman wawancara digunakan pada saat peneliti melakukan wawancara dengan guru dan siswa. Wawancara di sini untuk menggali informasi yang berhubungan dengan proses pembelajaran di kelas (3) Lembar Penilaian Diskusi Penilaian di sini untuk menilai tes kemampuan siswa dalam pembelajaran diskusi. Lembar penilaian keterampilan diskusi ini menggunakan penilaian berdasarkan Arsjad (2005: 87-89) yang telah dimodifikasi. terdapat dua faktor yang dinilai dalam keefektifan berbicara, yakni faktor kebahasaan dan faktor nonkebahasaan. Faktor kebahasaan mencakup: pengucapan vokal, pengucapan konsonan, penempatan tekanan, penempatan persendian, penggunaan nada/irama, pilihan kata, pilihan ungkapan, variasi kata, tata bentukan, struktur kalimat, dan ragam kalimat. Faktor nonkebahasaan meliputi: keberanian dan semangat, kelancaran, kenyaringan suara, pandangan mata, gerak-gerik dan mimik, keterbukaan, penalaran, dan penguasaan topic.

\section{HASIL DAN PEMBAHASAN PENELITIAN}

\section{Pratindakan Keterampilan Diskusi}

Siswa Keterampilan awal siswa dapat dilihat dari hasil tes pratindakan yang dilaksanakan sebelum implementasi tindakan. Untuk mengetahui skor rata-rata kelas tiap aspek keterampilan diskusi. Dilakukan penghitungan pada tiap aspek tersebut. Hasil penilaian kegiatan pratindakan keterampilan diskusi siswa sebelum implementasi tindakan disajikan dalam Tabel 1 berikut:

Tabel 1. Skor Penilaian Keterampilan Diskusi Siswa Pratindakan

\begin{tabular}{|l|l|c|c|c|}
\hline No. & \multicolumn{1}{|c|}{ Aspek } & $\begin{array}{c}\text { Jumlah } \\
\text { Skor }\end{array}$ & Rata-rata Kelas & Kategori \\
\hline 1. & Keberanian/semangat & 34 & 1,54 & $\mathrm{~K}$ \\
\hline 2. & Kelancaran berbicara & 31 & 1,41 & $\mathrm{~K}$ \\
\hline 3. & $\begin{array}{l}\text { Kejelasan ucapan dan pilihan } \\
\text { kata }\end{array}$ & 31 & 1,41 & $\mathrm{~K}$ \\
\hline 4. & Penguasaan masalah Pendapat & 32 & 1,45 & $\mathrm{~K}$ \\
\hline 5. & $\begin{array}{l}\text { Penyampaian } \\
\text { (persetujuan dan sanggahan) }\end{array}$ & & &
\end{tabular}

Keterangan:

BS : Baik Sekali dengan skor rata-rata kelas $\leq 5, \mathrm{~B}$ : Baik dengan skor rata-rata kelas $\leq$

4, C : Cukup dengan skor rata-rata kelas $\leq 3, \mathrm{~K}:$ Kurang dengan skor rata-rata kelas $\leq$

2, KS : Kurang Sekali dengan skor rata-rata kelas $\leq 1$

Berdasarkan Tabel 1 akan dideskripsikan keterampilan diskusi siswa secara lebih terperinci pada setiap aspek dalam kegiatan pratindakan.

1. Aspek keberanian/semangat ini berkaitan dengan kemampuan dan keberanian siswa dalam mengungkapkan ide dan menanggapi masalah. Selain itu, aspek ini juga berhubungan dengan sikap yang wajar dan tenang. Dari Tabel 3, dapat diketahui bahwa nilai rata-rata kelas keterampilan diskusi pada aspek keberanian/semangat sebebesar 1,54.

2. Aspek Kelancaran Berbicara Aspek ini berhubungan dengan kemampuan berbicara siswa, apakah masih tersendat dan berhenti, atau sudah benar-benar lancar. Berdasar hasil perolehan skor rata-rata kelas pada tabel 2, diketahui bahwa aspek kelancaran berbicara masih kurang. Hal ini tampak dari skor rata-rata kelas yakni sebesar 1,41. 
3. Aspek Kejelasan Ucapan dan Pilihan Kata: nilai rata-rata kelas pada aspek kejelasan ucapan adalah 1,41. Skor rata-rata aspek ini dalam kategori kurang dan menduduki peringkat yang sama dengan aspek kelancaran berbicara.

4. Aspek Penguasaan Masalah: Penguasaan topik, argumentasi, dan arah pembicaraan merupakan kriteria yang terdapat dalam aspek penguasaan masalah. Pada aspek ini siswa diharapkan mampu menguasai topik dan menyampaikan argumentasinya.

5. Aspek Penyampaian Pendapat (persetujuan dan sanggahan): Aspek penyampaian pendapat ini berhubungan dengan persetujuan dan sanggahan yang disampaikan oleh siswa. Apakah pendapatnya rasional dan disertai dengan alasan yang tepat atau tidak. Skor rata-rata siswa yang pada aspek ini sebesar 1,45.

\section{Hasil Penelitian Siklus I}

Dari hasil pengamatan yang dilakukan peneliti menunjukkan bahwa proses pelaksanaan tindakan masih belum maksimal dan masih belum sesuai rencana. Hal ini diperlihatkan dengan adanya beberapa siswa yang masih belum mengerti akan tugasnya, baik siswa yang bertamu maupun siswa yang tinggal di tempat. Akan tetapi, pada siklus ini siswa mulai berani dan percaya diri untuk berbicara, bertanya, dan mengeluarkan pendapat. Kekompakan dan saling kerjasama dalam kelompok sudah terlihat. Siswa mulai terlihat aktif dan beberapa sudah mampu memotivasi anggota lain dengan memberi arahan anggota lain yang belum begitu mengerti akan tugasnya. Namun, beberapa siswa terutama siswa laki-laki masih kurang mengerti dan kurang menguasai topik diskusi. Berikut ini adalah deskripsi data hasil pengamatan diskusi siklus I setiap kelompok pada Tabel 2.

Tabel 2. Pengamatan Proses Pembelajaran Diskusi Kelompok Siklus I

\begin{tabular}{|c|l|c|c|c|c|c|c|}
\hline No. & \multicolumn{1}{|c|}{$\begin{array}{c}\text { Aspek yang } \\
\text { Diamati }\end{array}$} & \multicolumn{6}{|c|}{ Kelompok } \\
\cline { 3 - 8 } & \multicolumn{1}{|c|}{ I } & II & III & IV & V & VI \\
\hline 1. & $\begin{array}{l}\text { Kekompakan } \\
\text { (saling kerjasama) }\end{array}$ & 3 & 3 & 3 & 3 & 3 & 3 \\
\hline 2. & $\begin{array}{l}\text { Memotivasi } \\
\text { anggota lain }\end{array}$ & 3 & 3 & 3 & 2 & 2 & 3 \\
\hline 3. & $\begin{array}{l}\text { Pengorganisasian } \\
\text { kerja kelompok }\end{array}$ & 3 & 3 & 3 & 2 & 3 & 2 \\
\hline 4. & $\begin{array}{l}\text { Inisiatif kerja } \\
\text { kelompok }\end{array}$ & 3 & 2 & 3 & 2 & 3 & 3 \\
\hline 5. & Keaktifan & 3 & 3 & 3 & 3 & 3 & 2 \\
\hline
\end{tabular}

Keterangan:

Skor 5 : keterampilan baik sekali (BS), Skor 4 : keterampilan baik (B), Skor 3 : keterampilan cukup (C), Skor 2 : keterampilan kurang (K), Skor 1 : keterampilan kurang sekali (KS)

Berdasar Tabel 2 dapat dideskripsikan bahwa secara keseluruhan keterampilan berdiskusi siswa dapat dikategorikan cukup baik. Hal ini menunjukkan peningkatan yang lebih baik dibandingkan dengan pada saat tes pratindakan. Siswa sudah cukup baik pada aspek kekompakan. Semua kelompok sudah menujukkan kekompakan dan saling kerjasama pada saat kegiatan berlangsung. Pada aspek memotivasi anggota lain masih ada dua kelompok yakni kelompok IV dan V yang masih dalam kategori kurang. Pada aspek pengorganisasian kerja kelompok, hampir semua kelompok sudah cukup baik. Hanya saja ada dua kelompok yakni kelompok IV dan VI yang masih kurang. Aspek inisiatif kerja kelompok sebagian besar sudah meningkat dibanding pada saat pratindakan.

Pada aspek ini ada dua kelompok yang tertinggal yakni kelompok II dan IV. Semua kelompok sudah aktif pada saat kegiatan diskusi berlangsung. Pada siklus I ini, kelompok VI masih kurang aktif. Secara keseluruhan, hampir semua aspek pada pengamatan proses 
pembelajaran ini meningkat. Penggunaan metode pembelajaran Two Stay Two Stray ini memberikan pengaruh yang cukup terlihat. Hal ini tampak pada keaktifan dan keberanian siswa. Dengan adanya siswa yang bertamu ke kelompok lain, memacu siswa untuk berbicara dan bertanya.

Pada pelaksanaan siklus I ini, diikuti oleh 22 siswa. Ada 1 orang siswa yang keluar dan terdapat 9 siswa yang tidak mengikuti pembelajaran karena mengikuti pelatihan baris-berbaris (paskibra) selama 1 bulan. Berikut adalah

Tabel 3. Peningkatan keterampilan diskusi siswa dari pratindakan ke siklus I

\begin{tabular}{|l|l|c|c|c|c|}
\hline No. & \multicolumn{1}{|c|}{ Aspek } & $\begin{array}{c}\text { Rata-rata } \\
\text { Skor } \\
\text { Pratindakan }\end{array}$ & $\begin{array}{c}\text { Rata-rata } \\
\text { Skor } \\
\text { Siklus I }\end{array}$ & Peningkatan & Kategori \\
\hline 1. & Keberanian/semangat & 1,54 & 2,82 & 1,28 & $\mathrm{C}$ \\
\hline 2. & Kelancaran berbicara & 1,41 & 2,41 & 1,00 & $\mathrm{C}$ \\
\hline 3. & $\begin{array}{l}\text { Kejelasan ucapan dan } \\
\text { pilihan kata }\end{array}$ & 1,41 & 2,5 & 1,09 & $\mathrm{C}$ \\
\hline 4. & Penguasaan masalah & 1,50 & 2,41 & 0,91 & $\mathrm{C}$ \\
\hline 5. & $\begin{array}{l}\text { Penyampaian } \\
\text { Pendapat } \\
\text { (persetujuan dan } \\
\text { sanggahan) }\end{array}$ & 1,45 & 2,45 & 1,00 & $\mathrm{C}$ \\
\hline \multicolumn{1}{|l|}{ Jumlah } & 7,31 & 12,59 & 5,28 & \\
\hline
\end{tabular}

Keterangan:

BS : Baik Sekali dengan skor rata-rata kelas $\leq 5, \mathrm{~B}$ : Baik dengan skor rata-rata kelas $\leq 4$,

$\mathrm{C}$ : Cukup dengan skor rata-rata kelas $\leq 3, \mathrm{~K}$ : Kurang dengan skor rata-rata kelas $\leq 2, \mathrm{KS}$

: Kurang Sekali dengan skor rata-rata kelas $\leq 1$

Diagram berikut merupakan diagram peningkatan keterampilan diskusi siswa dari pratindakan ke siklus I.

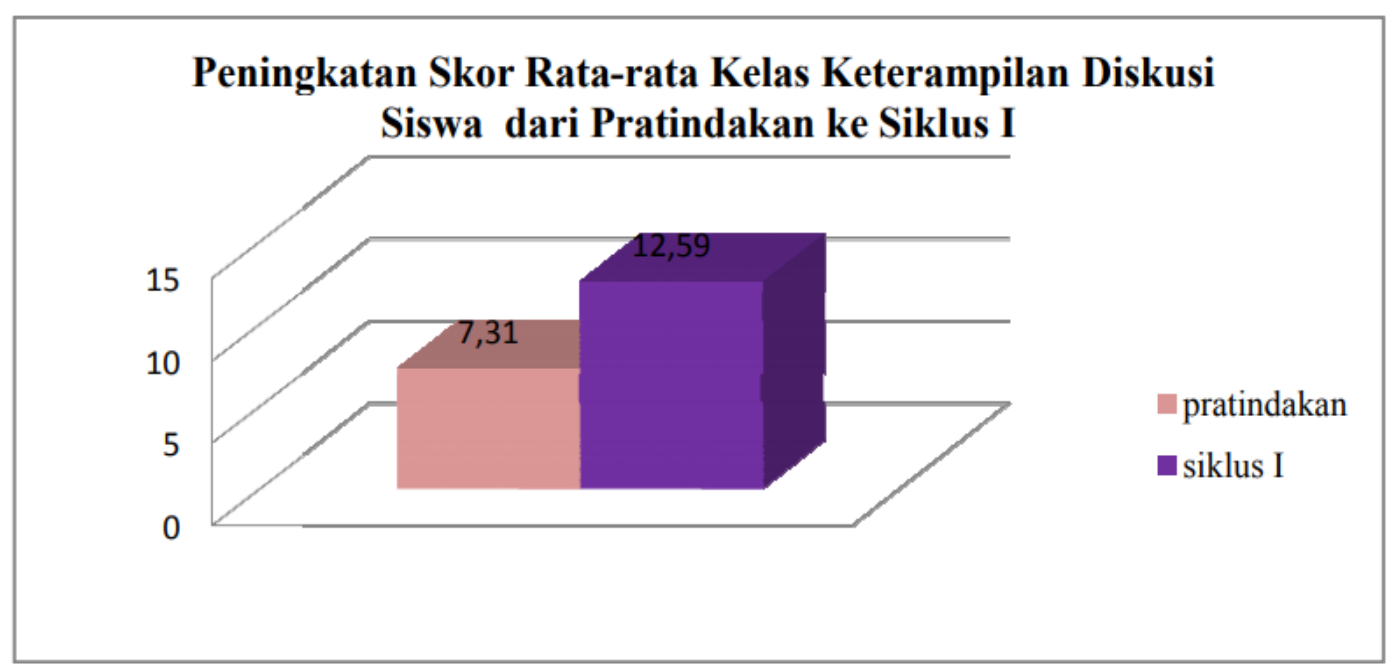

Gambar 1. Peningkatan skor rata pratindakan ke Siklus I

Dari data Tabel dan diagram di atas bahwa berbicara siswa terutama keterampilan diskusi mengalami peningkatan dari skor rata-rata kelas pratindakan 7,31 menjadi 12,59 pada siklus I 


\section{Hasil Penelitian Siklus II}

Pada pelaksanaan tindakan siklus II ini, kekompakan dan saling kerjasama siswa dalam kelompok sudah tergolong dalam kategori baik. Siswa mulai terlihat aktif dan beberapa sudah mampu melakukan pengorganisasian kelompok dengan baik. Berikut ini adalah deskripsi data hasil pengamatan diskusi siklus II setiap kelompok pada Tabel 4

Tabel 4. Pengamatan Proses Pembelajaran Diskusi Kelompok Siklus II

\begin{tabular}{|l|l|c|c|c|c|c|c|} 
No. & \multirow{2}{*}{ Aspek yang Diamati } & \multicolumn{7}{|c|}{ Kelompok } \\
\cline { 3 - 8 } & & I & II & III & IV & V & VI \\
\hline 1. & $\begin{array}{l}\text { Kekompakan (saling } \\
\text { kerjasama) }\end{array}$ & 4 & 4 & 4 & 4 & 4 & 4 \\
\hline 2. & $\begin{array}{l}\text { Memotivasi anggota } \\
\text { lain }\end{array}$ & 4 & 4 & 4 & 3 & 3 & 3 \\
\hline 3. & $\begin{array}{l}\text { Pengorganisasian } \\
\text { kerja kelompok }\end{array}$ & 4 & 4 & 4 & 3 & 4 & 3 \\
\hline 4. & $\begin{array}{l}\text { Inisiatif kerja } \\
\text { kelompok }\end{array}$ & 4 & 3 & 4 & 3 & 4 & 4 \\
\hline 5. & Keaktifan & 4 & 4 & 4 & 4 & 4 & 3 \\
\hline
\end{tabular}

Keterangan:

Skor 5 : keterampilan baik sekali (BS), Skor 4 : keterampilan baik (B), Skor 3 : keterampilan cukup (C), Skor 2 : keterampilan kurang (K), Skor 1 : keterampilan kurang sekali $(\mathrm{KS})$

Berdasarkan data Tabel 4 dapat dideskripsikan bahwa secara keseluruhan keterampilan berdiskusi siswa mengalami peningkatan yang lebih baik bila dibandingkan pada saat siklus I. Siswa sudah baik pada aspek kekompakan. Semua kelompok sudah menunjukkan kekompakan dan saling kerjasama pada saat kegiatan berlangsung. Pada aspek memotivasi anggota lain tergolong baik, pada aspek ini kelompok IV, V, dan VI masih tergolong cukup baik.

Dari hasil pengamatan bahwa siswa sudah mampu melaksanakan diskusi dengan metode pembelajaran Two Stay Two Stray ini dengan lancar. Siswa sudah berani pada saat berbicara dan tampak sangat bersemangat. Siswa juga terlihat sudah menguasai topik diskusi dan mampu menyampaikan argumentasi disertai alasan yang sesuai. Berikut ini adalah tabel deskripsi peningkatan keterampilan diskusi siswa dari siklus I ke siklus II.

Tabel 5. Peningkatan Keterampilan Diskusi Siswa dari Siklus I ke Siklus II

\begin{tabular}{|l|l|c|c|c|c|}
\hline No. & \multicolumn{1}{|c|}{ Aspek } & $\begin{array}{c}\text { Rata-rata } \\
\text { Skor Siklus } \\
\text { I }\end{array}$ & $\begin{array}{c}\text { Rata-rata } \\
\text { Skor Siklus } \\
\text { II }\end{array}$ & Peningkatan & Kategori \\
\hline 1. & Keberanian/semangat & 2,82 & 3,72 & 0,90 & B \\
\hline 2. & Kelancaran berbicara & 2,41 & 3,36 & 0,95 & B \\
\hline 3. & $\begin{array}{l}\text { Kejelasan ucapan dan } \\
\text { pilihan kata }\end{array}$ & 2,50 & 3,31 & 0,81 & B \\
\hline 4. & Penguasaan masalah & 2,41 & 3,31 & 0,90 & B \\
\hline 5. & $\begin{array}{l}\text { Penyampaian } \\
\text { Pendapat } \\
\text { (persetujuan dan } \\
\text { sanggahan) }\end{array}$ & 2,45 & 3,41 & 0,96 & B \\
\hline
\end{tabular}


Keterangan:

BS : Baik Sekali dengan skor rata-rata kelas $\leq 5$

B : Baik dengan skor rata-rata kelas $\leq 4$

C : Cukup dengan skor rata-rata kelas $\leq 3$

$\mathrm{K}$ : Kurang dengan skor rata-rata kelas $\leq 2$

KS : Kurang Sekali dengan skor rata-rata kelas $\leq 1$

Diagram berikut merupakan siswa dari siklus I ke siklus II

\section{Peningkatan Skor Rata-rata Kelas Keterampilan Diskusi Siswa dari Siklus I ke Siklus II}

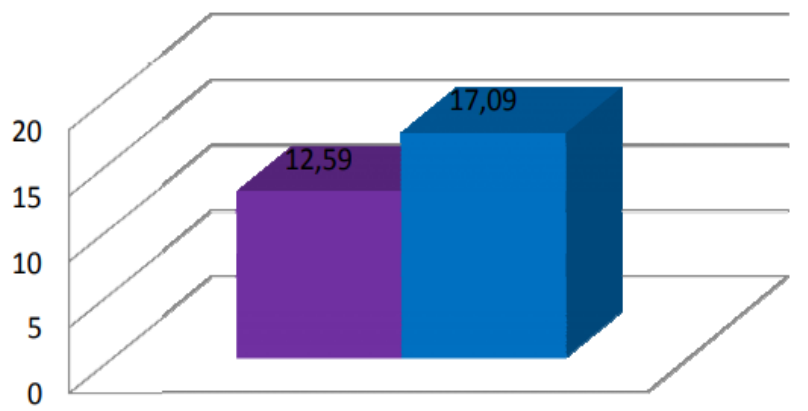

- Siklus I

- Siklus II

Gambar 2: Peningkatan Skor Rata Siklus I ke Siklus II.

Dari data Tabel 5 dan gambar 3 dapat disimpulkan bahwa kemampuan berbicara siswa terutama keterampilan diskusi mengalami peningkatan dari skor rata-rata kelas siklus I sebesar 12,59 menjadi 17,09 pada siklus II. Peningkatan skor rata-rata kelas dari siklus I ke siklus II sebesar 4,50. Ada beberapa aspek yang dinilai dalam diskusi meliputi: Keberanian/ semangat, Kelancaran penggunaan Bahasa, Kejelasan ucapan, Penguasaan masalah, dan, Aspek pendapat, inilah yang diamati oleh peneliti dalam penelitian ini (Dori Wuwur, 2009:45). Sementara itu, Tarigan (2008: 44-47) menjelaskan bentuk-bentuk diskusi yang lain yakni: Konferensi, tipe diskusi yang mengacu kepada action-taking discussion atau diskusi pengambilan tindakan, Dalam penelitian ini, bentuk diskusi yang dipakai adalah diskusi kelompok. Menurut Hasbulllah (2009: 64), dalam sebuah dikusi kelompok, tiap anggota kelompok hendaknya menyadari tujuan yang hendak dicapai, adanya hormatmenghormati, dan menghargai pendapat orang lain, serta bersikap tertib dalam bersoal jawab. Dalam sebuah kegiatan, tentunya dibutuhkan sebuah persiapan yang matang. Begitu pula dalam kegiatan diskusi, terdapat beberapa hal yang harus diperhatikan agar kegiatan diskusi dapat berjalan lancar.

Keberhasilan suatu diskusi ditentukan oleh matangnya persiapan yang meliputi: Pemilihan masalah yang akan dipakai sebagai pokok diskusi, Penentuan tujuan apa yang akan dicapai pada kegiatan diskusi, Memilih dan menentukan siapa-siapa yang akan diminta mengambil bagian dalam diskusi, Penjajagan masalah, Menentukan berapa lama waktu yang diperlukan untuk diskusi tersebut, Menentukan tata tertib dan jalannya diskusi, Menentukan kebutuhan fisik dan pengaturannya..

Sehingga pembahasan ini difokuskan pada (1) deskripsi awal keterampilan diskusi siswa, (2) pelaksanaan tindakan kelas denga.n metode pembelajaran Two Stay Two Stray, (3) peningkatan keterampilan diskusi siswa dengan metode pembelajaran Two Stay Two Stray, dan

(4) keterbatasan penelitian. Adapun penjelasannya adalah sebagai berikut.

1. Deskripsi Awal Keterampilan Diskusi Siswa

Tes keterampilan awal diskusi siswa dilakukan pada saat siswa melakukan diskusi kelompok dan diskusi kelas. Hal ini dilakukan untuk mengetahui keterampilan diskusi siswa sebelum implementasi/ pelaksanaan tindakan. Skor rata-rata kelas tiap aspek pada tahap pratindakan ialah (1) Aspek keberanian/semangat sebesar 1,54 (2) Aspek kelancaran berbicara sebesar 1,41 (2) Aspek kejelasan ucapan dan pilihan kata sebesar 1,41 (3) Aspek penguasaan masalah sebesar 1,5, dan (3) Aspek penyampaian pendapat (persetujuan dan 
sanggahan) sebesar 1,45. Secara keseluruhan, skor rata-rata kelas tiap aspek termasuk dalam kategori kurang. Sebagian besar siswa masih kurang berani untuk berbicara menyampaikan ide/argumentasi, kurang menguasai topik, dan kurang lancar dalam berbicara.

Situasi pembelajaran di kelas masih pasif. Siswa kurang aktif melakukan diskusi dan cenderung diam. Berdasarkan permasalahan-permasalahan tersebut, peneliti dan guru selaku kolabolator sepakat untuk menerapkan metode pembelajaran Two Stay Two Stray untuk meningkatkan keterampilan berbicara siswa khususnya keterampilan diskusi.

2. Pelaksanaan Penelitian Tindakan Kelas dengan Metode pembelajaran Two Stay Two Stray

Peneliti melakukan pengamatan terhadap pembelajaran diskusi siswa X IPA2 melalui observasi awal. Berdasarkan hasil pengamatan dan penilaian terhadap tindakan atau pada tahap pratindakan, diketahui masih banyak siswa yang kurang berani dalam menyampaikan ide/argumentasi, siswa masih belum lancar pada saat berbicara, siswa kurang memperhatikan kejelasan ucapan, diskusi, dan kemampuan siswa dalam berpendapat juga masih rendah. Situasi pembelajaran di kelas terlihat pasif dan belum terkondisi dengan baik.

Beberapa siswa tampak malas dan meletakkan kepalanya di meja dan membicarakan hal lain di luar topik diskusi. diambil pada saat pembelajaran berlangsung siswa tampak luar topik diskusi pada saat pratindakan untuk meningkatkan keterampilan berbicara siswa khususnya keterampilan diskusi. Pelaksanaan Penelitian Tindakan Kelas dengan Metode pembelajaran Two Stay Two Stray Peneliti melakukan pengamatan terhadap pembelajaran diskusi siswa X IPA2 melalui observasi awal. Hal ini sesuai dengan pendapat Ibrahim (2000) bahwa metode Pembelajaran Two Stay Two Stray ini memiliki banyak manfaat baik bagi guru maupun siswa itu sendiri. Manfaat Metode Pembelajaran ini bagi siswa yakni: (1) Melatih siswa untuk bekerjasama dalam kelompok (2) Mendorong siswa untuk dapat berbicara dalam sebuah diskusi (3) Merangsang kreativitas siswa selama pembelajaran berlangsung (4) Menarik minat siswa dalam melaksanakan pembelajaran di kelas, dan (5) Membantu siswa untuk lebih memahami topik diskusi secara lebih mendalam.

\section{KESIMPULAN}

Berdasarkan hasil penelitian serta pembahasan dalam penelitian tindakan kelas maka dapat disimpulkan bahwa Peningkatan hasil belajar dapat diketahui dari kemampuan berdiskusi siswa sebelum dikenai tindakan dan sesudah dikenai tindakan. Pada saat tes pratindakan, skor siswa masih tergolong kurang. Siswa masih terlihat diam, malu, dan kurang aktif melakukan diskusi. Siswa kurang berani menyampaikan ide/argumen dan kurang lancar dalam berbicara. Setelah dikenai tindakan (siklus II), kemampuan siswa mengalami peningkatan yang baik. Peningkatan keterampilan diskusi siswa dapat dilihat dari 5 aspek, yaitu (1) aspek keberanian/semangat, (2) aspek kelancaran berbicara, (3) aspek kejelasan ucapan dan pilihan kata, (4) aspek penguasaan masalah, dan (5) aspek penyampaian pendapat (persetujuan dan sanggahan). Peningkatan secara hasil belajar berdasarkan jumlah skor rata-rata kelas yang diperoleh yakni pada tes pratindakan sebesar 7,31 atau 29,63\%, pada siklus I meningkat menjadi 12,59 atau 50,54\%, pada siklus II meningkat menjadi 17,09 atau 68,36\%, dan pada akhir tindakan siklus II meningkat menjadi 20,90 atau 83,63\%.

\section{DAFTAR PUSTAKA}

Arsjad.,G.,M \& Mukti.,U.,S (2010) Pembinaan Kemampuan Berbicara Bahasa Indonesia. Jakarta: Erlangga.

Alvin A dan Carl E. Larson. 1985. Komunikasi Kelompok Proses-proses Diskusi dan Penerapannya. Jakarta: Universitas Indonesia Press Hendrikus.

Darsono., dkk (2000). Belajar dan Pembelajaran. Semarang: CV IKIP Semarang Press.

Dori Wuwur (2009) Retorika Terampil Berpidato, Berdiskusi, Berargumentasi, Bernegosiasi. Yogyakarta: Kanisius.

Hasbulllah (2009) Dasar-Dasar Ilmu Pendidikan. Jakarta: PT Raja Grafindo Persada. Ibrahim (2000). Pembelajaran Kooperatif. Surabaya: University Press. 
Iskandar (2009). Penelitian Tindakan Kelas. Jambi: GP Press.

Nurgiyantoro (2012) Penilaian dalam Pengajaran Bahasa dan Sastra. Yogyakarta: BPFE.

Susilo, Herawati, dkk (2009). Penelitian Tindakan Kelas Sebagai Sarana Keprofesionalan Guru dan Calon Guru. Malang: Bayumedia.

Tarigan, H.,G (2008) Menulis Sebagai Suatu Keterampilan Berbahasa. Bandung: Angkasa. 